\title{
Horticultural performance of Lee tangelo grafted onto six rootstocks in South Brazil
}

\author{
Mateus Pereira Gonzatto ${ }^{1 *}$, Alisson Pacheco Kovaleski², Gerson Nestor Böettcher ${ }^{3}$, \\ Renar João Bender ${ }^{3}$, Roberto Pedroso de Oliveira ${ }^{4} \&$ Sergio Francisco Schwarz ${ }^{3}$
}

\section{SUMMARY}

The objective of this study was to evaluate the performance of six rootstocks on vegetative growth, production and fruit quality of Lee tangelo for eleven growing seasons in Butiá, Rio Grande do Sul, Brazil. The evaluated rootstocks were: Swingle citrumelo, Caipira sweet orange, Troyer citrange, Rangpur lime, Volkamer lemon and Flying Dragon trifoliate orange. Trees grafted on Flying Dragon trifoliate orange and Volkamer lemon developed small canopy of spheroidal shape, while on the other rootstocks the canopy shape was ellipsoid. Fruit quality of Lee tangelo on all rootstocks was commercially appropriate, however the trees grafted on Volkamer lemon and Rangpur lime produced fruits with lower internal quality. Flying Dragon trifoliate orange and Volkamer lemon increased yield efficiency of the scion. The best yields for Lee tangelo was obtained on the Troyer citrange, Caipira sweet orange, Swingle citrumelo and Rangpur lime.

Index terms: fruit yield, fruit quality, tree size, alternate bearing, alternaria brown spot.

\section{Performance horticultural do tangeleirro Lee enxertado em seis porta-enxertos no Sul do Brasil}

\section{RESUMO}

O objetivo deste estudo foi avaliar o desempenho de seis porta-enxertos no crescimento vegetativo, produção e qualidade do fruto de tangeleiro Lee, por onze anos agrícolas em Butiá, Rio Grande do Sul, Brasil. Os porta-enxertos avaliados foram: citrumeleiro Swingle, laranjeira doce Caipira, citrangeiro Troyer, limoeiro Cravo, limoeiro Volkameriano e trifoliateiro Flying Dragon. As plantas enxertadas em Flying Dragon e em limoeiro Volkameriano desenvolveram copa pequena de formato esferoidal, enquanto que nos outros porta-enxertos o formato da copa foi a elipsoide. A qualidade dos frutos de tangeleiro Lee, em todos os porta-enxertos, foi classificada como comercialmente apropriada, no entanto, as plantas enxertanos limoeiros Volkameriano e Cravo produziram frutas com menor qualidade. Os porta-enxertos Flying Dragon e Volkameriano

\footnotetext{
${ }^{1}$ Estação Experimental Agronômica - EEA, Universidade Federal do Rio Grande do Sul - UFRGS, Eldorado do Sul, RS, Brazil

${ }^{2}$ School of Integrative Plant Science, Section of Horticulture, Cornell University, Ithaca, NY, USA

${ }^{3}$ Programa de Pós-graduação em Fitotecnia, Departamento de Horticultura e Silvicultura, Faculdade de Agronomia, Universidade Federal do Rio Grande do Sul - UFRGS, Porto Alegre, RS, Brazil

${ }^{4}$ Embrapa Clima Temperado, Monte Bonito, Pelotas, RS, Brazil

Corresponding author: Mateus Pereira Gonzatto, Estação Experimental Agronômica - EAA, Universidade Federal do Rio Grande do Sul-UFRGS, Rodovia BR-290, Km 146, Eldorado do Sul, CEP 92990-000, Eldorado do Sul, RS, Brazil. E-mail: mpgonzatto@gmail.com
} 
aumentaram a eficiência de produção do enxerto. As melhores produtividades para o tangeleiro Lee foram obtidas no citrangeiro Troyer, laranjeira doce Caipira, citrumeleiro Swingle e limoeiro Cravo.

Termos para indexação: produtividade de frutas, qualidade de fruta, tamanho da planta, alternância de produção, mancha marrom de alternaria.

\section{INTRODUCTION}

Lee tangelo [Citrus clementina Hort. ex Tan. $\times$ (C. tangerina Hort. ex Tan. $\times$ C. paradisi Macf.)] is a hybrid between Clementina tangerine and Orlando tangelo. The cross was made in Florida in 1942 (Hodgson, 1967). This cultivar has great vegetative vigor, and its fruits have high sugar and low acidity. The peel is smooth and glossy orange, and it is easily removed (Saunt, 1991; Hodgson, 1967). It is highly susceptible to Alternaria brown spot caused by Alternaria alternata. This is probably due to the fact that its parent Orlando originates from Dancy tangerine, which is highly susceptible to the ACT toxin of the tangerina pathotype of $A$. alternata (Reis et al., 2007). The fruits ripen in Rio Grande do Sul, Brazil, between mid April and late June (Sartori et al., 1998). Therefore, Lee could be used to diversify the tangerine production in this region. The fruit would be harvested between the harvest periods of Okitsu (C. unshiu) and Caí (C. deliciosa).

Rootstocks affect many characteristics of citrus plants: growth and development of the canopy, fruit yield and quality, and tolerance to various biotic and abiotic stresses (Castle, 1987). The rootstock can affect the behavior of some diseases that affect the canopy, such as citrus canker (Reis et al., 2008), citrus variegated chlorosis (CantuariasAvilés et al., 2011) and citrus leprosis (Andrade et al., 2013). Some effects have also been found in symptoms of huanglongbing, although these are not very well established (Shokrollah et al., 2011; Albrecht \& Bowman, 2012).

Diversity of rootstocks used in commercial citrus orchards is low. In Rio Grande do Sul state, $88 \%$ of the citrus farms have plants grafted onto Poncirus trifoliata, with $74 \%$ having exclusively this rootstock (Sulzbach et al., 2016). This is due to the cold resistance and the high fruit quality promoted by $P$. trifoliata (Schäfer \& Dornelles, $2000)$. In contrast, $70 \%$ of the oranges are grafted onto Rangpur lime in São Paulo state (Pompeu Júnior \& Blumer, 2008), a rootstock that increases drought resistance. The low diversity in rootstock use is a risk factor for the occurrence of new epidemics, such as those with citrus tristeza virus, citrus decline, Phytophthora spp. gummosis, and citrus sudden death (Castle, 2010). In this context, our objective was to evaluate vegetative and reproductive traits of Lee tangelo grafted onto six rootstocks in the Depressão Central region of Rio Grande do Sul state.

\section{MATERIAL AND METHODS}

The experiment was located in the Panoramas Citrus Farm, in Butiá, Rio Grande do Sul, Brazil $\left(30^{\circ} 07^{\prime} 58^{\prime \prime} \mathrm{S}\right.$, $51^{\circ} 51^{\prime 2} 22^{\prime \prime} \mathrm{W} ; 35 \mathrm{~m}$ altitude). The experiment was planted in August 1997 at a spacing of $6.0 \times 2.5 \mathrm{~m}\left(666.6\right.$ trees ha- $\left.{ }^{-1}\right)$. Six rootstocks were evaluated: Swingle citrumelo [C. paradisi Macf. $\times$ Poncirus trifoliata (L.) Raf.], Caipira sweet orange ( $C$. sinensis Osb.), Troyer citrange $(C$. sinensis $\times P$. trifoliata), Rangpur lime (C. limonia Osb.), Volkamer lemon (C. volkameriana Ten. \& Pasq.), and Flying Dragon trifoliate orange $[$ P. trifoliata var. monstrosa (T. Ito) Swing.]. The soil is a Paleudult, a Argissolo vermelho distrófico típico in the Brazilian soil classification (EMBRAPA, 2006), with 19\% clay. The climate of the region is a Cfa according to Köppen, with average annual temperature of $18.8^{\circ} \mathrm{C}$, average annual precipitation of $1445 \mathrm{~mm}$ and reference evapotranspiration of $1162 \mathrm{~mm}$ (Bergamaschi et al., 2013).

Phytosanitary practices and fertilization of the orchard were carried out according to usual commercial orchard practices, following regional recommendations (Koller, 2009). The vegetation between rows was mechanically mowed, and plants were manually thinned every year between February and March. Phytosanitary pruning was carried out in the winter of 2004. Fruit thinning and the phytosanitary pruning was performed according to the Koller (2009).

The trees were measured individually after the November growth flush, in January of 2004 and 2013. Height $(\mathrm{H})$, across-row diameter $\left(\mathrm{D}_{\mathrm{t}}\right)$, and in-row diameter $\left(D_{1}\right)$ were measured. The mean canopy diameter $\left(D_{M}\right)$ and the canopy shape index $\left(H / D_{M}\right)$ were calculated. The canopy volume $(\mathrm{V})$ was also calculated according to Zekri (2000), where $V=\left(\frac{\pi}{6}\right) \times H \times D_{t} \times D_{l}$ (Zekri, 2000). 
The rate of canopy growth $\left(\mathrm{m}^{3}\right.$ year $\left.{ }^{-1}\right)$ was also estimated through the variation of V between Jan 2004 and Jan 2013. Trunk circumference $\left(\mathrm{C}_{\mathrm{T}}\right)$ was measured $5 \mathrm{~cm}$ above the grafting union. The circumference $5 \mathrm{~cm}$ below the grafting union $\left(C_{R}\right)$ was measured only in 2013, and used to calculate the ratio between circumferences $\left(\mathrm{C}_{\mathrm{T}} / \mathrm{C}_{\mathrm{R}}\right)$.

Yield per plant was evaluated annually between 2001 and 2012, with the exception of 2006. The accumulated yield efficiency $\left(\mathrm{kg} \mathrm{m}^{-3}\right)$ was calculated by the ratio of the accumulated yield in the period and the canopy volume measured in January 2013. The alternate bearing index (ABI) was calculated as $A B I=\frac{1}{n-1} \times\left\{\left[\frac{\left|a_{2}-a_{1}\right|}{\left(a_{2}+a_{1}\right)}\right]+\left[\frac{\left|a_{3}-a_{2}\right|}{\left(a_{3}+a_{2}\right)}\right]+L+\left[\frac{\left|a_{n}-a_{n-1}\right|}{\left(a_{n}+a_{n-1}\right)}\right]\right\}$ (Pearce \& Dobersek-Urbanc, 1967), where $n$ is the number of years evaluated and $\mathrm{a}_{\mathrm{i}}$ is the yield per plant in the ith year. The ABI ranges from 0 to 1 , where values closer to 0 indicate more regular yields in the series of years evaluated.

Plants were harvested in May of each year. Between 2003 and 2012, 20 fruits per experimental unit were sampled for quality evaluation. Fruit weight, diameter (d), and height (h) were measured individually, and the ratio $\mathrm{h} / \mathrm{d}$ was used to estimate the shape of the fruit. The juice was then extracted, and evaluated for: juice content (\%), measured by the ratio juice weight/fruit weight; soluble solids (SS, \%), through refractometry; titratable acidity (TA, \%), measured by titrating $6 \mathrm{~g}$ of juice with $\mathrm{NaOH}$ $0.1 \mathrm{~mol} \mathrm{~L}^{-1}$ to $\mathrm{pH} 8.1$, expressed as the equivalent citric acid percent. The maturation index was calculated as the ratio SS/TA.

Between 2007 and 2012, color was also measured in the fruit samples in the equatorial region of the fruit. The measurements were made using a Konica-Minolta ${ }^{\circledR}$ CR-400 colorimeter, using the $L a b$ Hunter scale. In this scale, $L$ is the lightness, and $a$ and $b$ are color-opponent dimensions where $a$ ranges from green to red, and $b$ ranges from blue to yellow. From these measurements, the following parameters were calculated: citrus color index $[C I=1000 \times a /(L \times b)]$, chromaticity $\left[c=\sqrt{\left(a^{2}+b^{2}\right)}\right]$, and hue $\left[h^{o}=\arctan (b / a)\right]$. The CI represents a dark green when close to -20 , yellow at 0 , and intense orange when close to 20 (Jimenez-Cuesta et al., 1981). In 2011, incidence and severity of Alternaria brown spot in fruits was evaluated according to a scale developed by Renaud et al. (2008).

The theoretical optimal number of trees per hectare was calculated using the $\mathrm{D}_{\mathrm{M}}$ data from 2013. For this, an in-row overlap of $25 \%$ and a $2.5 \mathrm{~m}$ between canopies across-row distance were used (Negri et al., 2005).
The expected yield was then calculated using the yield per plant and the theoretical trees density (number of trees per hectare).

The experiment was arranged in a randomized complete block design (RCBD) with 96 plants total. The RCBD had six treatments (rootstocks) in four plant plots (experimental unit), with four replications (blocks). ANOVA was performed using PROC MIXED on SAS $9.4^{\circledR}$ (SAS Institute Inc, Cary, USA). For yield per plant, repeated measures were used, selecting covariance structures according to Akaike and Bayesian criteria. For other variables, the means were analyzed by year, and compared using Tukey-Kramer at $P<0.05$.

\section{RESULTS AND DISCUSSION}

In 2004, Lee grafted onto Caipira sweet orange, along with Troyer citrange, and Swingle citrumelo had the largest canopies (greatest $\mathrm{D}_{\mathrm{M}}, \mathrm{H}$, and $\mathrm{V}$ ), while trees on Rangpur lime, Volkamer lemon, and Flying Dragon trifoliate orange had the smallest (Table 1), although there was considerable overlap by mean separation. In 2013, similar behavior was seen, with the exception of Swingle that induced an intermediate V. The plants grafted onto Flying Dragon had the least canopy development in all aspects, but not differing statistically from trees on Volkamer. Lee grafted onto these two rootstocks had mean height of $2.25 \mathrm{~m}$ and $2.54 \mathrm{~m}$, and $16.5 \%$ and $26.4 \%$ of the $\mathrm{V}$ of the trees on Caipira, respectively.

The plants of Lee tangelo presented $\mathrm{H} / \mathrm{D}_{\mathrm{M}}$ between 1.1 and 1.4, which indicates a spheroidal (IPGRI, 1999) to ellipsoidal shape. In 2013, the canopies of Lee on Caipira, Rangpur, and Troyer had more columnar shapes. Volkamer and Flying Dragon resulted in more spheroidal canopies. Between 2004 and 2013, the rootstocks that provided greater canopy growth rates (Caipira, Troyer and Swingle) had a greater vertical than horizontal growth (Table 1). In contrast, the rootstocks with lower growth rates (Volkamer and Flying Dragon) maintained their canopy shapes.

The reduced vegetative growth of Lee grafted onto Flying Dragon is consistent with known characteristics as a dwarfing rootstock (Castle, 1978; Cheng \& Roose, 1995). This dwarfing effect of Flying Dragon was also observed in many varieties of tangerines, oranges, lemons, and Tahiti lime, in several environmental conditions (Cantuarias-Avilés et al., 2010, 2011, 2012; Gonzatto et al., 2011; Mademba-Sy et al., 2012; Silva et al., 2013). 
Table 1. Canopy mean diameter $\left(D_{M}\right)$, height $(H)$, shape index $\left(H / D_{M}\right)$, volume $(V)$, and growth rate $\left(G_{R}\right)$ in 2004 and 2013 of Lee tangelo grafted onto six rootstocks. Butiá, Brazil

\begin{tabular}{|c|c|c|c|c|c|c|c|c|c|}
\hline \multirow{2}{*}{ Rootstock } & \multicolumn{2}{|c|}{$\mathrm{D}_{\mathrm{M}}(\mathrm{m})$} & \multicolumn{2}{|c|}{$\mathrm{H}(\mathrm{m})$} & \multicolumn{2}{|c|}{$\mathrm{H} / \mathrm{D}_{\mathrm{M}}$} & \multicolumn{2}{|c|}{$\mathrm{V}\left(\mathrm{m}^{3}\right)$} & \multirow{2}{*}{$\begin{array}{c}\mathrm{G}_{\mathrm{R}} \\
\left(\mathrm{m}^{3} \text { year }^{-1}\right)\end{array}$} \\
\hline & 2004 & 2013 & 2004 & 2013 & 2004 & 2013 & 2004 & 2013 & \\
\hline Troyer & $1.98 \mathrm{a}^{\mathrm{a}}$ & $3.27 \mathrm{ab}$ & $2.29 \mathrm{ab}$ & $4.48 \mathrm{ab}$ & 1.18 & $1.37 \mathrm{a}$ & $5.05 \mathrm{ab}$ & $24.24 \mathrm{ab}$ & $2.13 \mathrm{ab}$ \\
\hline Caipira & $2.07 \mathrm{a}$ & $3.40 \mathrm{a}$ & $2.45 \mathrm{a}$ & $4.74 \mathrm{a}$ & 1.20 & $1.40 \mathrm{a}$ & $5.71 \mathrm{a}$ & $28.47 \mathrm{a}$ & $2.53 \mathrm{a}$ \\
\hline Swingle & $1.92 \mathrm{a}$ & $3.08 \mathrm{ab}$ & $2.14 \mathrm{ab}$ & $4.01 \mathrm{ab}$ & 1.14 & $1.31 \mathrm{ab}$ & $4.55 \mathrm{ab}$ & $19.53 \mathrm{~b}$ & $1.66 \mathrm{ab}$ \\
\hline Rangpur & $1.54 \mathrm{ab}$ & $2.77 \mathrm{bc}$ & $1.89 \mathrm{bc}$ & $3.86 \mathrm{~b}$ & 1.26 & $1.40 \mathrm{a}$ & $2.43 \mathrm{bc}$ & $15.49 \mathrm{bc}$ & $1.45 \mathrm{~b}$ \\
\hline Volkamer & $1.56 \mathrm{ab}$ & $2.32 \mathrm{~cd}$ & $1.78 \mathrm{bc}$ & $2.54 \mathrm{c}$ & 1.15 & $1.10 \mathrm{c}$ & $2.30 \mathrm{bc}$ & $7.53 \mathrm{~cd}$ & $0.58 \mathrm{c}$ \\
\hline Flying Dragon & $1.21 \mathrm{~b}$ & $1.98 \mathrm{~d}$ & $1.39 \mathrm{c}$ & $2.25 \mathrm{c}$ & 1.15 & $1.15 \mathrm{bc}$ & $1.07 \mathrm{c}$ & $4.70 \mathrm{~d}$ & $0.40 \mathrm{c}$ \\
\hline$P$ & 0.0009 & $<0.0001$ & 0.0001 & $<0.0001$ & 0.4331 & 0.0003 & 0.0009 & $<0.0001$ & $<0.0001$ \\
\hline
\end{tabular}

${ }^{a}$ Means followed by the same letter in the column are not significantly different by Tukey-Kramer's test $(\mathrm{P}<0.05)$.

Table 2. Trunk circumference above $\left(\mathrm{C}_{\mathrm{T}}\right)$ and below $\left(\mathrm{C}_{\mathrm{R}}\right)$ the grafting union and the ratio $\mathrm{C}_{T} / \mathrm{C}_{\mathrm{R}}$ in 2004 and 2013 of Lee tangelo grafted onto six rootstocks. Butiá, Brazil

\begin{tabular}{|c|c|c|c|c|}
\hline \multirow{2}{*}{ Porta-enxerto } & \multicolumn{2}{|c|}{$\mathrm{C}_{\mathrm{T}}(\mathrm{cm})$} & \multirow{2}{*}{$\begin{array}{c}C_{R}(\mathrm{~cm}) \\
2013\end{array}$} & \multirow{2}{*}{$\frac{\mathrm{C}_{\mathrm{T}} / \mathrm{C}_{\mathrm{R}}}{2013}$} \\
\hline & 2004 & 2013 & & \\
\hline Troyer & $25.5 \mathrm{ab}^{\mathrm{a}}$ & $47.2 \mathrm{ab}$ & $62.7 \mathrm{a}$ & $0.76 \mathrm{~b}$ \\
\hline Caipira & $26.9 \mathrm{a}$ & $54.7 \mathrm{a}$ & $61.6 \mathrm{a}$ & $0.89 \mathrm{a}$ \\
\hline Swingle & $22.3 \mathrm{ab}$ & $40.0 \mathrm{~b}$ & $73.1 \mathrm{a}$ & $0.55 \mathrm{c}$ \\
\hline Rangpur & $20.1 \mathrm{ab}$ & $41.1 \mathrm{~b}$ & $44.7 \mathrm{~b}$ & $0.92 \mathrm{a}$ \\
\hline Volkamer & $18.0 \mathrm{bc}$ & $30.7 \mathrm{c}$ & $34.4 \mathrm{~b}$ & $0.90 \mathrm{a}$ \\
\hline Flying Dragon & $11.9 \mathrm{c}$ & $21.2 \mathrm{~d}$ & $39.6 \mathrm{~b}$ & $0.54 \mathrm{c}$ \\
\hline$P$ & 0.0002 & $<0.0001$ & $<0.0001$ & $<0.0001$ \\
\hline
\end{tabular}

${ }^{a}$ Means followed by the same letter in the column are not significantly different by Tukey-Kramer's test $(\mathrm{P}<0.05)$.

The reduction in vegetative growth of Ponkan tangerine and Folha Murcha orange plants grafted onto Volkamer has also been seen when compared to rootstocks such as Rugoso lemon and Cleopatra tangerine in northwest Paraná state, Brazil (Stenzel et al., 2003, 2005). However, in most studies trees on Flying Dragon had smaller canopies compared to those on Volkamer (Espinoza-Nuñez et al., 2011; Gonzatto et al., 2011; Mademba-Sy et al., 2012; Silva et al., 2013), differently from what we observed (Table 1).

For the trunk circumference, especially in 2013, $C_{T}$ was greater on Caipira and Troyer, while Lee on Swingle and Rangpur had intermediate trunks (Table 2). Trees on Volkamer and especially Flying Dragon had significantly smaller $\mathrm{C}_{\mathrm{T}}$. The $\mathrm{C}_{\mathrm{R}}$ was greatest for trees on Swingle, Troyer, and Caipira. The smallest $C_{R}$ were seen for trees on in Flying Dragon, Rangpur, and Volkamer.
The $\mathrm{C}_{\mathrm{T}} / \mathrm{C}_{\mathrm{R}}$ ratio was close to 1 for Lee budded on Rangpur, Volkamer, and Caipira. Intermediate values were observed for trees on Troyer (0.76), and the lowest ratios were seen in trees on Swingle (0.55) and Flying Dragon $(0.54)$. The reduction in the $\mathrm{C}_{\mathrm{T}} / \mathrm{C}_{\mathrm{R}}$ ratio in plants grafted onto Swingle compared to more vigorous rootstocks has also been observed in a study with Marisol tangerine in Egypt (Bassal, 2009). The differential scion/rootstock trunk diameter effect of Flying Dragon has been observed in various citrus species (Mademba-Sy et al., 2012), and is proposed to be associated with the dwarfing mechanism of sap flux between canopy and rootstock pertaining to this rootstock (Yonemoto et al., 2004; MartínezAlcántara et al., 2013). Lower $\mathrm{C}_{\mathrm{T}} / \mathrm{C}_{\mathrm{R}}$ ratios may also be associated with a certain degree of incompatibility between canopy and rootstock varieties (Tazima et al., 2013), although this characteristic is not always associated with incompatibility (Barbasso et al., 2005). In our study with 16 year-old trees, no other signs of incompatibility have been found.

Rootstocks had a significant effect on fruit yield of Lee tangelo, with also significant variation between the years analyzed. The greatest cumulative fruit yields were found in plants grafted onto Troyer, which was not different from that of plants on Caipira, Swingle, and Rangpur (Table 3). The lowest yields were obtained from trees on Volkamer and Flying Dragon.

The accumulated yield efficiency for the period evaluated was greatest for Volkamer and Flying Dragon. The increment of yield efficiency of other canopies has already been reported for Flying Dragon compared to other rootstocks (Cantuarias-Avilés et al., 2010, 2011, 2012; Gonzatto et al., 2011; Mademba-Sy et al., 2012). For Span Americana tangerine, although an effect of 
rootstock was found, Flying Dragon promoted similar yield efficiency as Troyer and Carrizo tetraploids (Silva et al., 2013). It has been proposed that the higher yield efficiency of this rootstock is due to a lower translocation of sugars to the roots (MartínezAlcántara et al., 2013). The high yield efficiency of Lee on Volkamer has not been observed in other studies with other scions, where it was always similar to Rangpur lime (Georgiou, 2002; Stenzel et al., 2003; Espinoza-Nuñez et al., 2011; Gonzatto et al., 2011).

The ABI was not influenced by rootstocks (Table 3 ). The values found were always below 0.5, which indicates regular yields (Bassal, 2009). Similarly, other studies with tangerines and hybrids found no effect of rootstocks on ABI (Georgiou, 2000; Smith et al., 2004; Mourão Filho et al., 2007; Espinoza-Nuñez et al., 2007; Stuchi et al., 2008; Silva et al., 2013). This further demonstrates that other aspects (such as genetic characteristics of the canopy and management) may have greater impact on the production regularity by affecting the flowering intensity, which is greatly associated with fruit set (Gravina, 2007). Some studies, however, observed effects of the rootstocks on ABI in citrus (Georgiou, 2002; Stenzel et al., 2003, 2005; Cantuarias-Avilés et al., 2010, 2011, 2012).

The quality characteristics of the juice evaluated for Lee grafted onto all rootstocks tested were superior to the minimum international criteria (Table 4; OECD, 2010). However, only those grafted onto Flying Dragon produced fruit with $\mathrm{SS} \geq 10$ as required by regionally established criteria (Sartori et al., 1998). The fruits from plants grafted onto Volkamer had SS below the minimum criteria for tangerines $(\geq 9)$ in the southeastern region of Brazil (CEAGESP, 2000).

The fruit from trees on Rangpur and Volkamer had reduced JC and SS when compared to Flying Dragon (Table 4). Higher TA was also found in fruits of trees on Flying Dragon compared to other rootstocks, while the maturation index was not affected. A study by Georgiou (2000) evaluating Nova tangelo in Cyprus observed similar reduction in JC and SS in plants grafted onto Rangpur and Volkamer.

The fruits of Lee had greater mean diameter when grafted onto Rangpur compared to those grafted onto Flying Dragon (Table 4). The fruits from plants grafted onto Flying Dragon had a greater ratio h/d compared to Troyer, Swingle, and Rangpur, demonstrating a more round shape. Fruit weight and height were not affected by the rootstocks. The increase in the fruit diameter by
Rangpur was previously described for Nova tangelo (Georgiou, 2000), in Cyprus. This variety originates from the same crossing that produced Lee (Hodgson, 1967). Similarly, Koller et al. (2000) observed fruits of Hamlin sweet orange were flatter when grafted onto Rangpur, in Santa Catarina state, Brazil.

All rootstocks produced fruit with desirable color for export (Table 4), with CI > 2.0 (Spósito et al., 2006), and there was no effect of rootstock on this trait. This is in agreement with Stuchi et al. (2009), who found no differences in fruit coloration of Tahiti limes grafted onto different rootstocks. There was a high incidence of Alternaria brown spot on fruits of Lee. More than $80 \%$ of the fruit showed symptoms of the disease, demonstrating the high susceptibility of this cultivar to the disease (Reis et al., 2007). The severity of the symptoms were low, between 1.6 and $3.2 \%$, presenting a small number of spots or many spots of small diameter in each fruit. There was no effect of rootstock in this characteristic (Table 4). This is likely due to the symptoms affecting the pericarp of the fruit, and there was no effect of rootstocks on external or internal fruit maturation (Table 4).

The theoretical optimal spacing for trees of Lee on each rootstock (Table 5) was calculated according to orchard planning criteria (Negri et al., 2005), and followed the same trend as the vegetative growth aspects (Table 1). The optimal spacing for tree on rootstocks with greater canopy size (Caipira, Troyer, and Swingle) ranged between 2.3 and $2.6 \mathrm{~m}$ in-row and 5.6 and $5.9 \mathrm{~m}$ across-row spacing. This resulted in densities from 666.0 to 776.9 trees $\mathrm{ha}^{-1}$ (Table 5). The plants grafted onto Rangpur, of intermediate size, had an optimal density of 913 trees ha-1. For trees on Volkamer and Flying Dragon, the densities were 1193.3 and 1498.3 trees $^{-1} \mathrm{a}^{-1}$, respectively.

The calculated yields at optimal spacing were very similar between rootstocks, with the greatest expected yields from Lee grafted onto Volkamer $\left(19.5 \mathrm{t} \mathrm{ha}^{-1}\right)$, due to its great yield efficiency (Table 3 ). The low expected yield for trees on Flying Dragon is a result of its low vegetative growth (Table 1), despite its high yield efficiency. However, the expected yield for Lee was superior to similar spacing $(2.0 \times 4.0 \mathrm{~m})$ for Ponkan, Page, Clementina, and Unshiu tangerines, in Iran (Abedi Gheshlaghi et al., 2012), and Tahiti lime, in São Paulo (Stuchi et al., 2003), when grafted onto Flying Dragon. 

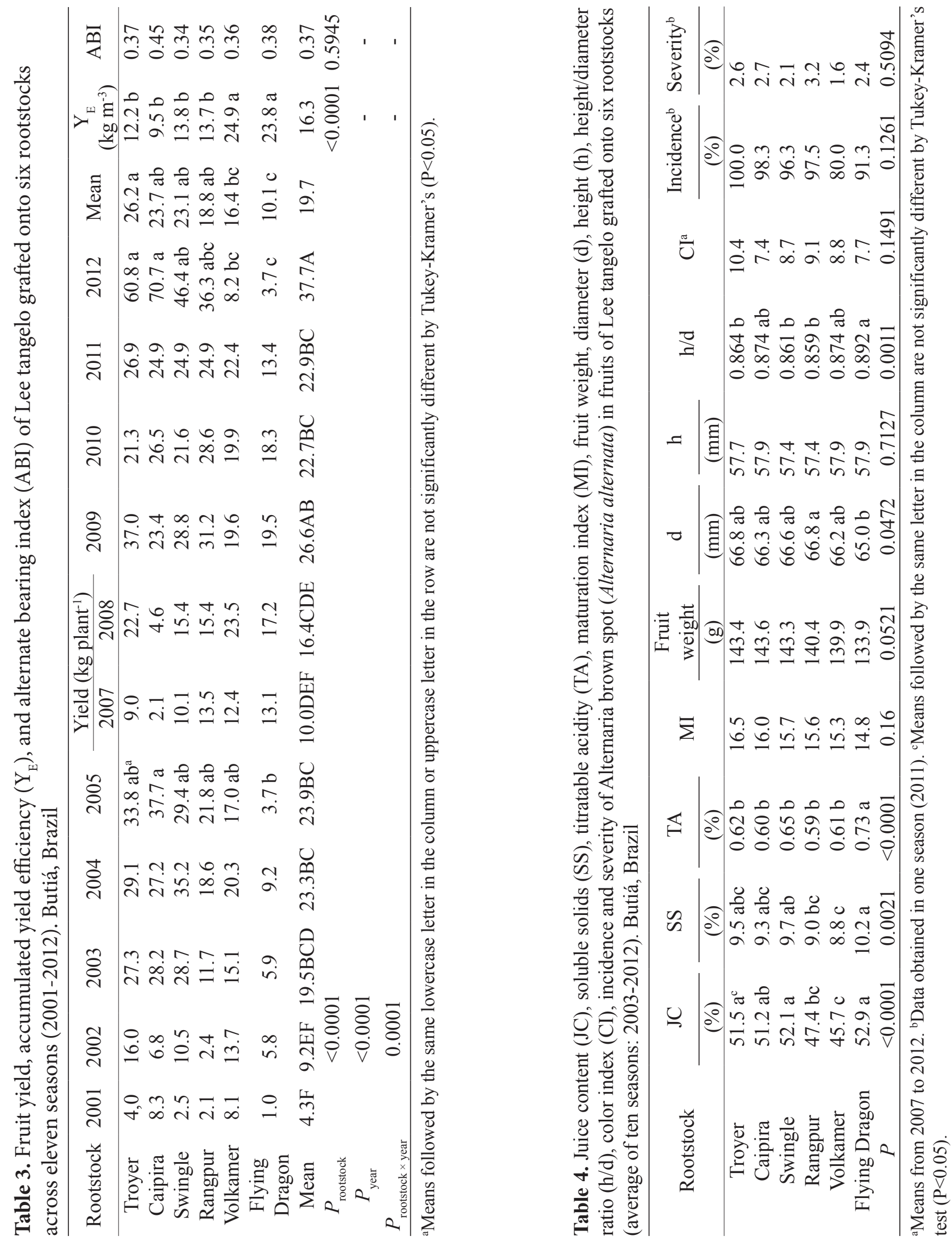
Table 5. Theoretical optimal in-row and across row spacing, tree density, and expected yield of Lee tangelo grafted onto six rootstocks. Butiá, Brazil

\begin{tabular}{ccccc}
\hline \multirow{2}{*}{ Rootstock } & \multicolumn{2}{c}{ Spacing $^{\mathrm{a}}(\mathrm{m})$} & \multirow{2}{*}{ Tree density $\left(\right.$ trees ha $\left.^{-1}\right)$} & \multirow{2}{*}{ Expected yield $^{\mathrm{b}}\left(\mathrm{t} \mathrm{ha}^{-1}\right)$} \\
\cline { 2 - 4 } & in-row & across-row & 706.0 & 18.5 \\
Troyer & 2.5 & 5.8 & 666.0 & 15.8 \\
Caipira & 2.6 & 5.9 & 776.9 & 17.9 \\
Swingle & 2.3 & 5.6 & 913.0 & 17.1 \\
Rangpur & 2.1 & 5.3 & 1193.3 & 19.5 \\
Volkamer & 1.7 & 4.8 & 1498.3 & 15.1 \\
Flying Dragon & 1.5 & 4.5 &
\end{tabular}

${ }^{a}$ Calculated according to Negri et al. (2005). ${ }^{b}$ Expected yield $=$ tree density $\times$ yield per plant (Table 3 ).

\section{CONCLUSIONS}

Lee grafted onto Troyer citrange, along with Caipira sweet orange, Swingle citrumelo, and Rangpur lime produced the greatest yields. The greatest yield efficiency was obtained in plants grafted onto Volkamer lemon and Flying Dragon trifoliate orange.

All rootstocks led to commercially acceptable quality parameters in fruits of Lee tangelo, with the worst internal quality found in Volkamer lemon and Rangpur lime. The color of the fruits was not affected by the rootstock.

Lee tangelo canopies have an ellipsoidal shape, with exception of those grafted onto Flying Dragon trifoliate orange and Volkamer lemon, which had reduced vegetative growth, and resulted in more spheroid canopies.

\section{REFERENCES}

Abedi Gheshlaghi E, Fifaei R, Javadi Majaddad D \& Farzam E (2012) Study of planting density of four mandarin cultivars on 'Flying Dragon' rootstock. International Journal of AgriScience 2(12): 1093-1102.

Albrecht U \& Bowman KD (2012) Tolerance of trifoliate citrus rootstock hybrids to Candidatus Liberibacter asiaticus. Scientia Horticulturae 147: 71-80.

Andrade DJ, Falconi RS, Siqueira DS, Barbosa CL, Ferraudo AS \& Oliveira CA (2013) The influence of citrus rootstocks on the relationship between the mite Brevipalpus phoenicis and citrus leprosis disease. Pest Management Science 69(1): 81-87.

Barbasso DV, Pio RM \& Carvalho AS (2005) Compatibilidade de variedades e híbridos de tangerinas enxertadas em citrumelo 'Swingle'. Laranja 26: 59-67.
Bassal MA (2009) Growth, yield and fruit quality of Marisol Clementine grown on four rootstocks in Egypt. Scientia Horticulturae 119(2): 132-137.

Bergamaschi H, Melo RW, Guadagnin MR, Cardoso LS, Silva MIG, Comiran F, Dalsin F, Tessari ML \& Brauner P. Boletins agrometeorológicos da Estação Experimental Agronômica da UFRGS. Porto Alegre: UFRG, 2013. (Série Histórica 1970-2012). Available from: <http:// www.ufrgs.br/agronomia/eea>. Accessed: 20 Jan. 2016.

Cantuarias-Avilés T, Mourão Filho FAA, Stuchi ES, Silva SR \& Espinoza-Núñez E (2010) Tree performance and fruit yield and quality of 'Okitsu' Satsuma mandarin grafted on 12 rootstocks. Scientia Horticulturae 123(3): 318-322.

Cantuarias-Avilés T, Mourão Filho FAA, Stuchi ES, Silva SR \& Espinoza-Núñez E (2011) Horticultural performance of 'Folha Murcha' sweet orange onto twelve rootstocks. Scientia Horticulturae 129(2): 259-265.

Cantuarias-Avilés T, Mourão Filho FAA, Stuchi ES, Silva SR, Espinoza-Núñez E \& Bremer Neto H (2012) Rootstocks for high fruit yield and quality of 'Tahiti' lime under rain-fed conditions. Scientia Horticulturae 142: 105-111.

Castle WS (1978) Controlling citrus size with rootstocks and viruses for higher density plantings. Proceedings of the Annual Meeting of the Florida State Horticultural Society 91: 46-50.

Castle WS (1987) Citrus rootstocks. In: Rom RC \& Carlson RF (Eds). Rootstocks for fruits crops. New York: John Wiley and Sons, p. 361-399.

Castle WS (2010) A career perspective on citrus rootstocks, their development, and commercialization. HortScience 45(1): 11-15. 
CEAGESP - Companhia de Entrepostos e Armazéns Gerais de São Paulo (2000) Programa brasileiro para a melhoria dos padrões comerciais e embalagens de hortigranjeiros: classificação de tangerinas. São Paulo: CEAGESP. (Folder).

Cheng FS \& Roose ML (1995) Origin and inheritance of dwarfing by the Citrus rootstock Poncirus trifoliate 'Flying Dragon'. Journal of the American Society for Horticultural Science 120(2): 286-291.

EMBRAPA (2006) Centro nacional de pesquisa de solos: sistema brasileiro de classificação de solos. 2. ed. Rio de Janeiro: Embrapa, 306 p.

Espinoza-Nuñez E, Mourão Filho FAA \& Stuchi ES (2007) Desenvolvimento vegetativo, produção e qualidade de frutos da tangerina 'Fremont' sobre quatro porta-enxertos. Revista Brasileira de Fruticultura 29: 308-312.

Espinoza-Nuñez E, Mourão Filho FAA, Stuchi ES, Cantuária-Avilés T \& Dias CTS (2011) Performance of 'Tahiti' lime on twelve rootstocks under irrigated and nonirrigated conditions. Scientia Horticulturae 129: 227-231.

Georgiou A (2000) Performance of 'Nova' mandarin on eleven rootstocks in Cyprus. Scientia Horticulturae 84: 115-126.

Georgiou A(2002) Evaluation of rootstocks for 'Clementine' mandarin in Cyprus. Scientia Horticulturae 93: 29-38.

Gonzatto MP, Kovaleski AP, Brugnara EC, Weiler RL, Sartori IA, Lima JG, Bender RJ \& Schwarz SF (2011) Performance of 'Oneco' mandarin on six rootstocks in South Brazil. Pesquisa Agropecuária Brasileira 46(4): 406-411.

Gravina A (2007) Aplicación del ácido giberélico en Citrus: revisión de resultados experimentales em Uruguay. Agrociencia 11(1): 57-66.

Hodgson RW (1967) Horticultural varieties of citrus. In: Reuther W, Webber HJ \& Batchelor LD (Eds). The citrus industry. Riverside: University of California, p. 431-591.

IPGRI (1999) Descriptors for citrus. Roma: International Plant Genetic Resources Institute, 66 p.

Jimenez-Cuesta M, Cuquerella J \& Martinez-Javaga JM (1981) Determination of a color index for citrus fruits degreening. Proceedings of Intenational Society of Citriculture 2: 750-753.
Koller OC (2009) Citricultura: cultura de tangerineiras - tecnologia de produção, pós-colheita, industrialização. Porto Alegre: Rígel, 400 p.

Koller OL, Soprano E \& Costa ACZ (2000) Avaliação de porta-enxertos para laranjeira 'Hamlin' em Santa Catarina. Revista Ceres 47: 325-336.

Mademba-Sy F, Lemerre-Desprez Z \& Lebegin S (2012) Use of Flying Dragon trifoliate orange as dwarfing rootstock for citrus under tropical climatic conditions. HortScience 47: 11-17.

Martínez-Alcántara B, Rodriguez-Gamir J, Martínez-Cuenca MR, Iglesias DJ, Primo-Millo E \& Forner-Giner MA (2013) Relationship between hydraulic conductance and citrus dwarfing by the Flying Dragon rootstock (Poncirus trifoliata L. Raft var. monstruosa). Trees 27(3): 629-638.

Mourão Filho FAA, Espinoza-Nuñez E, Stuchi ES \& Ortega EMM (2007) Plant growth, yield, and fruit quality of 'Fallglo' and 'Sunburst' mandarins on four rootstocks. Scientia Horticulturae 114: 45-49.

Negri JD, Stuchi ES \& Blasco EEA (2005) Planejamento e implantação do pomar cítrico. In: Mattos Junior D, Negri JD, Pio RM \& Pompeu Junior J. (Orgs). Citros. Campinas: Instituto Agronômico e FUNDAG, p. 409-427.

OECD (2010) International standards for fruit and vegetables: citrus fruits. Paris: Organization for Economic Operation and Development, $244 \mathrm{p}$.

Pearce SM \& Dobersek-Urbanc S (1967) The measurement of irregularity in growth and cropping. Journal of Horticultural Science 42: 295-305.

Pompeu Júnior J \& Blumer S (2008) Laranjeiras e seus porta-enxertos nos viveiros de mudas cítricas do estado de são Paulo. Laranja 29(1-2): 35-50.

Reis B, Koller OC, Schwarz SF, Theisen S, Sartori IA, Nichele FS, Lorscheiter R \& Petry HB (2008) Produção de frutos e incidência de cancro cítrico em laranjeiras 'Monte Parnaso' enxertadas sobre sete porta-enxertos. Ciência Rural 38: 672-678.

Reis RF, Almeida TF, Stuchi ES \& Goes A (2007) Susceptibility of citrus species to Alternaria alternata, the causal agent of the Alternaria brown spot. Scientia Horticulturae 113: 336-342.

Renaud MSA, Amorim L, Lourenço SA \& Spósito MB (2008) Diagrammatic scale for assessment of Alternaria 
Brown spot of citrus. Summa Phytopathologica 34(3): 270-271.

Sartori IA, Schäfer G, Schwarz SF \& Koller OC (1998) Épocas de maturação de tangerinas na depressão central do Rio Grande do Sul. Revista Brasileira de Fruticultura 20: 313-322.

Saunt J (1991) Variedades de cítricos del mundo. Valencia: Edipublic, 128 p.

Schäfer G \& Dornelles ALC (2000) Produção de mudas cítricas no Rio Grande do Sul - diagnóstico da região produtora. Ciência Rural 30(4): 587-592.

Shokrollah H, Abdullah TL, Sijam K \& Abdullah SNA (2011) Potential use of selected citrus rootstocks and interstocks against HLB disease in Malaysia. Crop Protection 30: 521-525.

Silva SR, Stuchi ES, Girardi EA, Cantuaria-Avilés T \& Bassan MM (2013) Desempenho da tangerineira 'Span Americana' em diferentes porta-enxertos. Revista Brasileira de Fruticultura 35: 1052-1058.

Smith MW, Shaw RG, Chapman JC, Owen-Turner J, Lee LS, Mcrae KB, Jorgensen KR \& Mungomery WV (2004) Long-term performance of 'Ellendale' mandarin on seven commercial rootstocks in sub-tropical Australia. Scientia Horticulturae 102: 75-89.

Spósito MB, Julianetti A \& Barbasso DV (2006) Determinação do índice de cor mínimo necessário para a colheita de laranja doce valência a ser submetida ao processo de desverdecimento. Laranja 27(2): 373-379.

Stenzel NMC, Neves CSVJ, Gomes JC \& Medina CC (2003) Performance of 'Ponkan' mandarin on seven rootstocks in southern Brazil. HortScience 38: 176-178.

Stenzel NMC, Neves CSVJ, Scholz MBS \& Gomes JC (2005) Comportamento da laranjeira 'Folha Murcha' em sete porta-enxertos no Noroeste do Paraná. Revista Brasileira de Fruticultura 27: 408-411.

Stuchi ES, Donadio LC \& Sempionato OR (2003) Performance of Tahiti lime on Poncirus trifoliata var. monstrosa Flying Dragon in four densities. Fruits 58: 1-5.

Stuchi ES, Espinoza-Núñez E, Mourão Filho FAA \& Ortega EMM (2008) Vigor, produtividade e qualidade de frutos de quatro tangerineiras e híbridos sobre quatro porta-enxertos. Revista Brasileira de Fruticultura 30: 741-747.

Stuchi ES, Martins ABG, Lemo RR \& Cantuarias-Avilés T (2009) Fruit quality of 'Tahiti' lime (Citrus latifolia Tanaka) grafted on twelve different rootstocks. Revista Brasileira de Fruticultura 31: 454-460.

Sulzbach M, Oliveira RP, Waquil PD, Girardi EA, Gonzatto MP, Böettcher GN \& Schwarz SF (2016) Characterization of citrus farms production systems used in Rio Grande do Sul, Brazil. Abstract Book of International Citrus Congress. Campinas, Londrina, p. 53.

Tazima ZH, Neves CSVJ, Yada IFU \& Leite Júnior RP (2013) Performance of 'Okitsu' Satsuma Mandarin on nine rootstocks. Scientia Agrícola 70(6): 422-427.

Yonemoto Y, Matsumoto K, Furukawa T, Asakawa M, Okuda H \& Takahara T (2004) Effects of rootstock and crop load on sap flow rate in branches of 'Shirakawa Satsuma' mandarin (Citrus unshiu Marc.). Scientia Horticulturae 102: 295-300.

Zekri M (2000) Citrus rootstock affect scion nutrition, fruit quality, growth, yield and economical return. Fruits 55: 231-239.

Received: November 15, 2016 Accepted: January 17, 2017 